\title{
THE ITALIAN CRIMINAL COURT OF PADOVA SENTENCED THE CIRCUS' DIRECTOR FOR CRUELTY TO ANIMALS
}

Carla Campanaro ${ }^{1}$

On July $13^{\text {th }}, 2016$ the Italian Criminal Court of Padova issued an eight month sentence to the director of the Medrano Circus, for cruelty to animals as per article 544 ter of the Italian Penal Code, as "he gratuitously caused physical and psychological damage to animals - notably exotic species - who have been medically treated directly on the circus premises, having been subjected to treatment that was incompatible with their ethological needs." A team of veterinarians helped the Prosecutor find evidence of the crime, delivering all the expertise to the Tribunal, which confirmed the bad conditions in which the animals were kept. In this case, the crime of mistreatment was based by the judge on the environmental conditions the animals were obliged to live in, depriving them of all their ethological needs. The presence of an independent veterinarian specialized in exotic animals was decisive for the public accusation. The elephant and the kangaroo were confiscated.

LAV joined civil proceedings as a civil party, supporting the public inquiry, obtaining a sentence that represents the culmination of years of work by numerous associations which began cooperating on the case in December, 2012, when the Medrano Circus' tent was being set up in Padua. Inspections first carried out by volunteers and then by the official authorities, revealed the appalling and inadequate conditions in which the animals were being kept, conditions that were incompatible with their ethological needs ${ }^{2}$.

\footnotetext{
${ }^{1}$ Attorney at law in Rome and Head of LAV Legal Office.

${ }^{2}$ For further information, see:

http://corrieredelveneto.corriere.it/veneto/notizie/cronaca/2016/13-luglio-2016/canguri-edelefanti-stressati-condannato-circo-medrano-240677579628.shtml http://mattinopadova.gelocal.it/padova/cronaca/2016/07/13/news/maltrattamenti-suglianimali-condannato-il-circo-medrano-1.13811869
} 